\title{
TAXATION IN AID OF FARM SECURITY
}

\author{
Russell J. Hinckley* AND John J. HAGgerty**
}

Recent concern over insecurity of farm tenure and related conditions has given rise to proposals for adoption of various tax devices or modifications of the property tax system, of themselves, or supplementary to more direct measures, to aid in the promotion of farm security. These proposals have usually implied some form of differential taxation to favor the resident owner-operator and the small holding, or to penalize the absentee owner and the large holding. Others are designed to curb speculative land holdings or transactions. The usual premises are ( $\mathrm{I}$ ) that tenancy per se is undesirable and (2) that real estate tax burdens, absentee ownership, large holdings, and land speculation are prominent among the forces which tend to prevent the residents and operators from owning their homes and their farms. Without attempting to explore the validity of these premises, this article is intended to consider certain tax devices which have been proposed with particular regard to their possible effectiveness in accomplishing the desired end, namely, owner-operation of family-size farms, and their potential effects in other directions.

It should be recognized that the general problem of encouraging farm ownership by operators has two distinct phases, i.e., maintaining present ownership against the various forces of reversion, and promoting the step from tenancy to ownership for those who have not been able to achieve it. The same tax measures may not serve both purposes or, as will be subsequently shown, measures designed to serve the one may actually impede the other.

Differential taxation usually implies either preferential treatment in taxation favorable to some class of property, type of industry, or direction of development which it is considered desirable to encourage, or discriminatory taxation against some class of property, industry, or development which public policy sets out to discourage. In either case, the concept of differential taxation presumes a classification of property, through the use of which will result a difference in the effective rate of taxation on the property being considered relative to other classes of property. The

* A.B., 1931, A.M., 1932, Wesleyan University; Ph.D., 1934, Cornell University. Agricultural Economist, Farm Security Administration, U. S. Department of Agriculture. Author: State Grants-in-Aid (New York State Tax Commission, 1935).

* B.S., I933, Montana State College; M.S., I934, University of Wisconsin. Agricultural Economist, Farm Security Administration, U. S. Department of Agriculture.

This article constitutes the opinion of the writers and does not represent official views of the Farm Security Administration. 
effective rate of taxation, for example, may be made to differ from the nominal tax rate by variations in the method or level of assessment of different classes of property to which the nominal rate applies. In the process of securing preferential tax treatment for owner-operated family-size farms, a necessary prerequisite would obviously be a classification of property designed to differentiate the homestead from other real property holdings. This classification, as will be subsequently shown, can be established in most states only by statute, and in about half the states only by constitutional amendment. ${ }^{1}$ The classification law must necessarily define the homestead in terms of owner-occupancy and size of holding, the latter to be expressed in dollars of valuation, or acreage, or both. ${ }^{2}$ The legal question raised by the regulatory aspects of such classification will be subsequently discussed.

- According to the National Industrial Conference Board, State and Local Taxation of Property (1930) 395, I7 states had constitutional provisions requiring uniformity; 5 had no requirement, but some degree of classification was permitted by judicial interpretation; Io had constitutional provisions permitting classification with restrictions as to types of property, and 16 permitted it without restriction. Those with provisions requiring uniformity were: Arkansas, Georgia, Illinois, Indiana, Mississippi, Missouri, Nevada, North Carolina, New Hampshire, Ohio (as to real estate), South Carolina, Tennessee, Texas, Utah, Washington, West Virginia, Wyoming. Since that date, however, Arkansas, Texas, Utah, West Virginia, Georgia, and North Carolina have permitted homestead exemption by specific amendment. Georgia by amendment also permitted classification into tangible and two or more classes of intangible including money and adoption of different rates for different classes. North Carolina adopted an amendment permitting much broader classification. Mississippi and Wyoming enacted homestead exemption laws. The sixteen states whose constitutions permit classification without restriction were: Arizona, Colorado, Delaware, Idaho, Iowa, Kentucky, Louisiana, Minnesota, Montana, New Jersey, North Dakota, Oklahoma, Oregon, Pennsylvania, South Dakota, Virginia. The five permitting classification by judicial interpretation were: Connecticut, Alabama, New York, Rhode Island, and Vermont. The ten with constitutional provisions permitting classification with restriction were: California (limited to enumerated intangibles); Florida; Kansas (limited to minerals and mining products; Maine (limited to intangibles); Maryland; Massachusetts (limited to forests); Michigan (rate must be equivalent to average rate on other property based on ad valorem basis); Nebraska; New Mexico; Wisconsin (no power to exempt any class). Since 1930, Florida has permitted homestead exemption by constitutional amendment.

The differential treatment desired, assuming the basis of classification set forth above, might be secured by any one or a combination of the following several methods:

First, by the adoption of differential rates of taxation for different classes of property and the assessment of such property at true value or at a uniform percentage of true value. This method of securing diffcrential taxation is necessarily statutory in origin and, if inconsistent with the constitution of the state in which adopted, it will be declared illegal by the courts.

Second, by the adoption of fractional assessments varying with different classes of property to which a uniform ad valorem rate is applied. Undervaluation per se is not classification. In order to constitute classification the rates of assessment must vary with the classes and must be uniform within each class of property. A common motive for the adoption of varying assessments has been the hope that constitutional requirements of uniformity in rates may be evaded through the application of uniform rates to varying assessments.

Third, by adoption of assessments at fixed amounts which represent varying percentages of the true. value of the different classes of property, and the application to these fixed assessments of uniform ad tralorem rates. This device has been used in a number of states to relieve from taxation young stock, non-productive personality, and types of property easily concealable and therefore not likely to be assessed unless accorded preferential treatment.

Fourth, by the adoption of varying assessment methods for different classes of property through the application of which varying percentages of true value are arrived at in the assessment process. This procedure is usually extra-legal rather than statutory in origin, though it may result from assessment of certain property by the state (as in the case of utilities) and other property by local assessors. The application of uniform rates to the varying percentages of true value would obviously result in differences in the effective rates of taxation.

Fifth, by the adoption of varying, partial, or qualified exemptions which would cause different per- 
It should be recognized that the concept of differential taxation is not new in tax theory or practice. It has always been the practice of governments to exempt some property from taxation. In colonial days exemptions and other forms of preferential treatment were more prevalent than today. In the movement for uniform and universal taxation of property throughout the nineteenth century, many preferences and exemptions disappeared. That movement having apparently run its course, the demand for exemptions has again become insistent, and there is an increasing "nibbling away" of the tax base through exemptions granted for a great variety of reasons. $^{3}$

\section{Recent Homestead Exemption Measures}

During the past four years, there has been a wave of agitation throughout the country for exemption of all or part of the assessed valuation of legal homesteads from taxation. Exemption measures have been defended mainly on the ground of assisting in the maintenance of present small home and farm ownership against tax reversion, mortgage foreclosure, or other forces contributing to insecurity. The movement is also connected with general efforts toward property tax relief, the particular adjustment contemplated being to modify the tax in conformity to ability to pay, and to counteract tendencies toward regressive assessment of small properties. The exemption device has also been put forward as a measure to promote new ownership and construction.

Legislatures in at least thirty, if not all, of the states have had bills or resolutions introduced on the subject. Permissive measures have been enacted, or laws are in actual operation, in at least fifteen states. Several new measures are to be submitted to voters in the 1938 elections.

Definition of the homestead becomes a matter of considerable administrative importance. The definition accepted may be that given by the state constitution for judicial purposes or that set up specifically by the legislature in the act. The usual general provisions of exemption laws are that: $(x)$ the taxpayer seeking exemption shall be a citizen and resident of the state; (2) he shall own and occupy the property in question; (3) the property shall come within the constitutional or statutory concept of a homestead; and (4) exemption from property taxes shall not include special assessment or improvement liens, nor, very frequently, debt service levies on prior

centages of true value to be taxed at the regular uniform ad valorem rates. These exemptions may vary in time, in amount, or in elements of property exempted, as where a portion rather than the whole of a class is exempt, or they may free certain property from given taxes to which other holdings are subject.

Sixth, preference may be granted in other ways, as in the case of Nebraska in the years following 19ry, during which mortgages were taxed as an interest in the land, while the value of the mortgage was deducted from the assessment of the land. Unanticipated repercussions led to the subsequent abandonment of this policy.

See Lejand, The Classified Property Tax in the United States (1928) c. 2, passim.

${ }^{3}$ Jensen, Property Taxatron in the United States (1931) 125.

"May, Status of Homestead Exemption in the United States (May 1937) 13 J. of Land and Pun. UT. EcoN. 130 . 
debt in order that bondholders' contracts not be impaired.4 ${ }^{4}$ Too frequently, the statutory definition of homestead is loosely drawn, permitting, under actual local administration, more widespread extension of exemption than originally contemplated. ${ }^{5}$ Obscure definition has also occasioned, in a number of instances, a series of judicial decisions, until a body of interpretation is developed.

Florida, by constitutional amendment ${ }^{\mathbf{6}}$ adopted in November 1934, exempts from all taxation, other than special assessments, all homesteads up to the valuation of \$5000. However, the State Supreme Court has held that homesteads cannot be exempted from taxes for debt outstanding prior to enactment of the law, nor issues refunding such debt. ${ }^{7} \mathrm{New}$ homes would likewise be subject to taxes for retirement of indebtedness as such buildings become attached to the land and the value of land and buildings is combined into one assessment for tax purposes. The Florida amend,ment is mandatory and self-executing, not a mere enabling act such as that passed in Oklahoma and certain other states. It represents the most liberal exemption measure of this type passed to date.

Louisiana likewise adopted a homestead exemption amendment in 1934 which provides only partial and contingent exemption. ${ }^{8}$ Exemption is extended from state, parish, and special taxes to homesteads not exceeding 160 acres and the buildings and appurtenances, whether rural or urban, owned and occupied by every head of family or person with dependents, to a value of $\$ 2000$. This exemption does not extend to municipal or city taxes, (with one exception ${ }^{9}$ ). Moreover, homestead exemption

\footnotetext{
4he latter point has commonly been made in the courts rather than in the laws.

'In Florida, the law requires that the recipient of exemption (rural homesteads not more than 160 acres, urban homes not more than one-half acre, exemption not to exceed $\$ 5,000$ in assessed value) be head of a family, a citizen and resident of Florida, use the property for a permanent home, and possess a legal or beneficial title in equity to property located in the state. Fla. Laws 1935, c. 17060. The Florida law apparently makes it possible for owners of houses now rented to obtain homestead status for the property by substituting purchase contracts. Under present conditions, a large portion of residential property and much small hotel, apartment, and business property could become eligible for the $\$ 5,000$ excmption, including many not actually occupied by owners, occupied in part, or only for a temporary period.

The Mississippi law, Miss. Laws 1934, c. I91, attempts to be more explicit on many points. The taxpayer seeking relief must be head of a family, resident of the state, hold fee simple title or life estate to the property claimed as legal homestead. In certain cases, a lease of school lands will satisfy ownership requirements of the law. No part of the building located on the homestead may be used for business purposes except that the owner may rent not more than five rooms in the dwelling to tenants or boarders. Where there are apartment buildings consisting of two or more separate apartments, only the portion occupied by the owner may be included in the homestead. Nor more than one exemption is permitted on one building, or buildings with a common owner or owners. In municipalities the exemption is confined to contiguous and adjoining lots on the same street. If the homestead is less than roo acres and under $\$ 2,500$ in assessed value, the head of a family claiming exemption is permitted to select an additional tract or tracts nearest that on which the dwelling is located, as long as the total area is less than I60 acres, and valuation under $\$ 2,500$. Only one homestead is permitted to a family group. If the dwelling is destroyed by fire, storm, etc., and the owner must move temporarily to another place, his right of exemption continues for one year after the event.

${ }^{\circ}$ FLA. Const., Art. X, $\$ 7$.

${ }^{7}$ Boatright v. Jacksonville, iry Fla. 477,158 So. 42 (1934).

${ }^{9}$ LA. Const., Art. X, \$4, approved Nov. 6, 1934; La. Acts 1934, No. 78 .

'Orleans Parish, in which the City of New Orleans is located. In this parish exemption applies to state, general city, school, levee, and levee board taxes.
} 
from parish or special taxes would not be extended in an amount greater than the funds available in the "Property Tax Relief Fund," to reimburse the state and subdivisions for tax losses entailed by the exemption.

In Minnesota, the principle of de facto exemption of homesteads, through the process of classification of property for taxation, was adopted by the 1933 legislature. ${ }^{10}$ The law provides that assessments on rural homesteads shall not exceed $20 \%$ for the first $\$ 4000$ of full and true value, while additional value above this amount and all other rural real estate are taxed (as previously) on $33-1 / 3 \%$ of full value. Urban homesteads are taxed on $25 \%$ of full and true value up to $\$ 4000$, while any additional value and all other urban realty is assessed (as previously) at $40 \%$ of true value. Under this law the favor accorded homesteads by classification is tantamount to a limited exemption. Rural homesteads are accorded greater favor than urban. The State Supreme Court ruled that there was no violation of the uniformity clause of the constitution since the taxes are uniform on the same class of subjects. ${ }^{11}$

The I934 legislature of the State of Mississippi enacted a law exempting from state ad valorem taxes only, homes up to $\$ 1000$ in assessed value, provided the homestead did not exceed 40 acres in extent. ${ }^{12}$ The claimant taxpayer must be head of a family and a resident of the state. In 1935, the law was amended as described previously, to increase the maximum exemption to $\$ 2500$ and the limit on size to I60 acres. ${ }^{13}$

Texas voters in I933 approved an amendment providing exemption of resident homesteads not exceeding 200 acres in extent from state taxes on the first $\$ 3000$ of assessed valuation. ${ }^{14}$

West Virginia in 1932 granted some preference to homesteads through classification and a series of property tax limitations. Although the chief purpose of this amendment was to reduce the burden of the general property tax, one of its incidental purposes and effects was to discriminate in favor of all agricultural property, whether occupied by owner or tenant and residential property owned by the occupants. The rate limit on "property owned, used, and occupied by the owner exclusively for residential purposes" and "farms ... occupied and cultivated by their owners or bona fide tenants" was fixed at $\$ 1.00$ per $\$ 100$ assessed value. Other real property, however, may, under the terms of this amendment, be taxed up to limits of $\$ 1.50$ or $\$ 2.00$, depending upon whether it is situated within or without an incorporated municipality. ${ }^{15}$

Arkansas, at the election of November 6, 1936, approved the exemption of resident homesteads (actually occupied by the owner) from state taxes up to $\$ 1000$ assessed

\footnotetext{
${ }^{20}$ Minn. Laws I933, c. 359.

11 Apartment Operators' Ass'n v. Minneapolis, 19I Minn. 365, 254 N. W. 443 (1934).

${ }^{20}$ Miss. Laws I934, c. I91.

${ }^{13}$ Miss. Laws 1935, c. 22 . ${ }^{14}$ Texas Const., Art. VIII, 51 -a.

${ }^{25}$ For text of this amendment, see W. Va. Laws 1932, Ex. Sess., c. 9. South Dakota also exempted homesteads from all taxation for state purposes (S. D. Laws 1937, C. 209), although the state does not now levy a property tax.
} 
valuation. The legislature was authorized to fix the amount of exemption from time to time between a $\$ 2500$ maximum and a $\$ 1000$ minimum. It was charged, however, with the duty of enacting the necessary legislation and of replacing any funds affected, but not of enacting any new form of tax. Bondholders' rights were to be protected. ${ }^{16}$

At the general election on November 3, I936, Utah ratified an amendment providing that the legislature may make provisions for exemption of homes, homesteads and personal property, not to exceed $\$ 2000$ in value of homes and homesteads, and $\$ 300$ for personal property. ${ }^{17}$

North Carolina at the November 1936 election ratified a homestead exemption amendment providing that the General Assembly may exempt from taxation not exceeding $\$ 1000$ of value of property held and used as a place of residence of the owner. ${ }^{18}$ The wording of the amendment would quite apparently not exempt homes occupied by tenants or renters.

In September r935, the people of Oklahoma decided to amend the constitution by initiated petition to provide for homestead exemption. The ratified plan (petition) charged the legislature with the duty of defining a homestead and determining the maximum exemption. Once determined, the law may not be changed for twenty years, except to raise the amount of exemption. ${ }^{19}$

On June 8, 1937, the Georgia electorate adopted a constitutional amendment exempting resident homesteads (actually occupied by the owner) up to a value of \$2000 from all ad valorem taxes and reserved the right in the General Assembly to lower it to \$1250. ${ }^{20}$ The effective date was not specified.

Iowa provided that the balance of proceeds of the personal net income tax, the business tax on corporations, and the retail sales tax (after allocating $3 \%$ to the Old Age Pension Fund and $\$ 500,000$ to the Emergency Relief Fund) should be held as a homestead exemption credit fund, apportioned each year to give credit against the tax on each eligible homestead in the state in the proportion which the assessed valuation of the homestead bears to the assessed valuation of all eligible homesteads in the state in amount not to exceed $\$ 2500$ each. ${ }^{21}$

Wyoming and Alabama also enacted statutes extending homestead exemption in

${ }^{15}$ For the text of this amendment, see Ark. Laws 1937, Act. No. 247.

${ }^{17}$ For the text of this amendment, see Utah Laws 1935, p. 257 (permissive only).

${ }^{13}$ For text of this amendment, see N. C. Pub. Laws 1935, P. 745 (permissive only). The legislature would not be required to grant the full $\$ \mathrm{r}, 000$ exemption. It could grant an exemption of lesser amount or none at all. At this same election, an amendment of broader terms was ratified permitting classification of property and the levying of different tax rates or applying different scales of valuation to each class.

In 1937 the state legislature considered and rejected a bill providing for a $\$ 300$ exemption.

${ }^{29}$ For text of this amendment, see Okla. Laws 1935 , p. 399 . In 1937 a measure was adopted exempting one acre urban, I60 acres rural, up to \$1000 valuation. Okla. Laws I937 (Ex. Sess.) H. B. 3.

${ }^{20}$ For text of this amendment, see Ga. Laws 1937, p. II22.

${ }^{21}$ Iowa Laws 1933, H. F. I, as amended by lowa Laws 1937, S. F. 84. A homestead is defined as "a small plot of. land with a home in which the owner lives." One-half acre is the maximum size in the city or town, maximum assessed valuation being $\$ 2,500$, and 40 acres the maximum in rural areas.

The exemption does not apply to taxes in excess of 25 mills. 
1937..$^{21^{*}}$ Wyoming exempts resident homesteads from state and local taxes up to $\$ 500$ valuation, revenue losses to be replaced by a homestead property exemption fund. Alabama provided that exemption should not exceed \$2000 assessed valuation of every homestead as defined by constitution and laws, area not to exceed I60 acres.

\section{Appraisal of Homestead Exemption}

Local governments derive the greater part of their revenues from taxes on general property. Any major change in the property tax system would have far-reaching effects upon state and local governmental revenue systems. Among the practical aspects of homestead exemption or other devices for preferential taxation of homesteads is the general question of effects upon local governmental finance and services. More specifically, would the individual benefits derived be sufficiently great to justify a serious disturbance of present financial arrangements? Secondly, what is the likelihood that the tax preference granted homesteads might not fall back upon the home owner in the form of reductions of essential services, or in other, indirect taxes?

Estimates of the reduction in tax base and tax revenues by.homestead exemption measures have been made in a number of instances. ${ }^{22}$ In Alabama, it was found that in one county an exemption of $\$ 2000$ of true value would reduce assessable property values for state, county, and school purposes $16 \%{ }^{23}$ The Florida League of Municipalities estimated ${ }^{24}$ that the $\$ 5000$ exemption measure adopted in 1934 would remove from the tax rolls about $15 \%$ of the full value of taxable property in the state. In Georgia, a proposed exemption of $\$ 5000$ was estimated as holding possibility of reducing present assessed values one-third. About $93 \%$ of the total value of farm property was shown to be made up of parcels valued at $\$ 5000$ or less. ${ }^{25} \mathrm{~A}$ proposed Montana exemption up to $\$ 2500$ assessed value was viewed as threatening a loss of 40 to $60 \%$ in assessed values of certain counties and 40 to $75 \%$ in many cities. In about 1000 school districts (one-half the school districts of the state), such a measure would reduce taxable valuations as much as $75 \%{ }^{26}$ Corresponding estimates in a number of other states show generally similar results. ${ }^{27}$

Reductions such as these in general property tax returns would necessarily require either drastic curtailment of present services, shifts in tax burden to non-exempt property by increasing tax rates or assessments, or a more fundamental shift in the revenue system away from general property taxation to some other revenue device, such, for example, as the sales tax. Whether preferential treatment of homesteads

ma Wyo. Laws 1937, c. 140; Ala. Laws $5936-37$, (Sp. Sess.) p. 107, S. 5.

2 C. Paige, The Exempsion of Homesteads from Taxation (Ám. Legislators' Ass'n, May 6, 1935).

${ }^{2}$ Knight, The Effects of the Proposed Homestead Exemption in Alabama on Tax Reventues of Tuserloosa County, Univ. of Ala., Bergat of Brsixess Research, Stcdits of Legislatjve Problems in Alabara, Mim. Scr. No. 5, Pr. 2 (193t).

${ }^{24} \mathrm{Fla}$. League of Municipalities, FlA. Municspal. Record, Oct. J934.

× Property Tax Exemptions and Rate Limitations (Ass'n of County Comm'rs of Ga., Jan. 1935) 17.

${ }^{26}$ Note (Feb. 1937) 26 Nat. Mus. Rev. 95.

2: May, Estimating the Effects of Homestead Tax Exemption (Aug. 1937) 13 J. of LaND AND PUD. UT. ECoN. 307. 
would actually operate in their favor, would ultimately depend upon the nature of replacement measures adopted. In a number of states, specific or over-all rate limitations would prevent shifting of the tax burden, where rates are already at or near the legal maximum. The use of the sales tax for purposes of relieving small home owners of real estate tax burdens has elsewhere been characterized as "taxing the poor to help the poor." The recent general resort to sales taxes would undoubtedly receive further impetus as a result of homestead exemption. In fact, a number of recent exemption bills have carried provision for general sales taxes as substitute revenue measures.

Assuming that recourse may be had to replacement tax measures more equitable than the sales tax, the usual exemption device may reduce the tax burden on the small income home owner, but does nothing for tenants with small incomes. When, as is usually the case, the definition of the homestead runs strictly in terms of owneroccupancy, the measure favors only persons able and willing to own their own. homes. ${ }^{28}$ The tenant, bearing at least that part of the real estate tax burden on non-exempt property which is shifted, is placed at a relative disadvantage. The burden shifted might be noticeably increased should local revenue losses be made up by higher rates on remaining non-exempt valuation.

While tax reductions in the aggregate, as a result of moderate homestead exemption, would present serious revenue problems for state and local governments, the benefits accorded individuals under typical measures would not be great, and could easily be offset by their contributions under replacement measures. This is particularly true of exemptions from state taxes of say, five to ten mills on a low valuation limit. Likewise, if the annual tax reductions involved should be sufficient to constitute an inducement to purchase on the part of prospective home-owners, there would be a tendency on the part of the seller to capitalize them in the purchase price.

There exists little question as to the desirability of general property tax reform, but the homestead exemption measure has no merit from the point of view of a just distribution of tax burdens. It may actually increase the inequities of the tax system and the difficulties of its administration, ${ }^{29}$ The approach might better be in the direction of more scientific assessment and collection processes, or, if tax relief to real estate is to be accorded, it should not take place in the restricted and unscientific manner apparent in exemption devices. Rather, the change should embrace

${ }^{23}$ A critic of the recent Iowa law, supra note 2I, supposedly to promote purchase and ownership of homesteads and to combat the increase in tenancy, stated: "Once it is functioning, the law will provide a mild kind of a redistribution of wealth, but apparently in the direction of taking, through the sales $\operatorname{tax}$ and the burden on tenants, from those that have not to give to those who are a least able to own their own homes. In short, tho tenant gets no relief as he continues to pay the part of the real estate tax that is shifted to him, and in addition is burdened with a two percent tax upon his general purchases, his utility services and his amusements." Root, lowa's Tax Refund Law for Homesteads (May 1937) 26 NAT. MUN. REv. 259.

${ }^{2}$ For example, inequities due to widely different levels of assessment among minor taxing jurisdictions. Moreover, home owners as a class are relieved from taxation regardless of ability to pay. 
broader replacement or realignment of revenue sources in the tax system as a whole where possible; income and business taxes would be desirable replacement measures for real estate taxes. The rapidity of the shift would have to be geared to the condition of state tax administration and state aid system.

\section{Graduated Land Taxes}

One instance of foreign measures of differential taxation designed to discourage absentee holding, break up large estates, and bring idle or under-utilized land into use is the graduated land tax as adopted in Australia. The Commonwealth Parliament had no power to pass direct land legislation or regulate tenure; hence its only means of attacking this problem was by tax measures. ${ }^{30}$ The Commonwealth land tax is levied at graduated rates on unimproved capital value. Two schedules of rates are provided, one applying to land absentee-owned, the other to land not absentee-owned. Both schedules penalize large holdings, but the tax is always heavier on the former to penalize absentee ownership. This tax was first imposed in I9ro-II, when the rate of tax was I and I/30,000 penny on the first pound in excess of an unimproved value of $£ 5000$, increasing by $1 / 30,000 \mathrm{~d}$. for every additional pound up to $£ 75,000$, where the increment of tax was $6 \mathrm{~d}$. and the average rate $3 \frac{1}{2} \mathrm{~d}$. The increment of tax of $6 \mathrm{~d}$. operated only on the excess of $£, 75,000$. The general exemption of $£_{5} 5000$ did not apply to absentees, the rate for whom was always $\mathrm{I} d$. more than for residents, and the first $\mathcal{L}_{5000}$ of value for an absentee bore a flat rate of I d. per pound. In 1914-15 the rate of tax was amended by making the tax on I pound I I $/ \mathrm{x} 875^{\circ} \mathrm{d}$., increasing by $\mathrm{I} / \mathrm{I} 8750 \mathrm{~d}$. for each additional pound, up to $£ 75,000$. The increment on value in excess of $\oint_{0} 75,000$ was at the rate of $9 \mathrm{~d}$. per pound. Absentees correspondingly paid I d. per pound more than residents. A $20 \%$ increase which was imposed in I9r8-19 was withdrawn in 1922-23 and a further reduction of $10 \%$ was granted in $1927-28$. No further alteration was made in the rates until $1932-33$, when a reduction of $33-1 / 3 \%$ was made, and in the following year the rates were further reduced to $50 \%$ of those effective in $1927-28 .^{31}$

In addition to the Commonwealth land tax, the states in Australia likewise levy various land taxes on unimproved land values, some of which discriminate against absentee owners and some against undeveloped land, while others are graduated according to valuation without other specific discrimination.

The plan has apparently only partially achieved its purpose. Its early administration was beset with a heavy volume of litigation and evasion. The decline in large holdings immediately before and after passage of the tax plan was in part due to anticipation of severe discrimination and in part due to nominal rather than real transfers. Special concessions to holders in early months gave some incentive to sale to tenants on easy terms, subdivisional sales, or sales to the government for closer settlement. It has been contended that, even without the tax, a decline in large

${ }^{s o}$ The desire to meet heavy demands for land and small holdings was a part of the background for this legislation.

${ }^{31}$ Official Yearbook of the Commonwealth of Australia (Comm. Bureau of Census and Statistics, 1936), No. 29, Pp. $845-846$. 
estates would have occurred, due to: (I) division of lands under settlements and wills; (2) government purchases of land for returned soldiers; (3) a period of good prices inducing subdivision and sale. ${ }^{32}$

A substantial differential enjoyed by properties of small size and value may induce large holders to sell, but may not actually operate to reduce the price to purchasing tenants or to improve their relative financial position. Much more depends upon the adoption of direct policies by the government with regard to promoting purchase and settlement. There is some question as to the desirability of penalizing size alone in a large ranching country unless it can be demonstrated that the land can be broken up for wheat and mixed farming and put to better use at an early date.

New Zealand also imposed a national graduated land tax until I93I, when it was replaced by an income tax. ${ }^{33}$ Its repeal was due more to the effects of the depression on net farm incomes than a change in viewpoint. "The graduated land tax, continually revised to make it more penal against the large estates, may not have been as decisive an inducement to subdivision as hoped, but it did reinforce the pressure of such other tendencies as rising prices and increasing land demand."34 Other related forces making for closer settlement were growth of population, family subdivision, and state repurchase laws.

The record of administration reveals a flood of early evasion, continued increases in rates, and great practical difficulties in valuation. ${ }^{35}$ The severity of the higher graduations of the national tax was less significant than the liberality of exemptions extended to the small holder: Aggregate local rates (ungraduated) and urban progressive land taxes and income taxes were much heavier on both large and small holders. "The graduated land tax may, perhaps, be summed up by saying that it hindered the growth of land aggregation, contributed in an unassessable degree to the break-up of large estates, while avoiding, through its exemptions, all obstacles to the development of small farms. As a revenue device, it has had little importance."36

Taxation of unimproved values of land, as employed in Australia and New Zealand, is almost necessarily a corollary of classification on the basis of absentee or nonabsentee ownership, since the intent is not to discourage the ownership or the

"Heaton, The Taxation of Unimproved Value of Land in Australia (I925) 39 Q. J. EcoN. 433-434.

${ }^{2} \mathrm{~A}$ flat rate tax on unimproved value was retained with mortgage exemptions (graduated according to unimproved value) and a reduced minimum taxable valuation in order that it apply to a greater percentage of farmers. New legislation was also added to strengthen compulsory land purchase or lease to establish small holdings, although economic conditions were not favorable to action.

"Belshaw, Williams et al, Agricultural Organization in New Zealand (N. Z. Inst. of Pacific Relations. Melbourne Univ. Press, 1936) 22.

s Such as segregating value of certain improvements,from the value of the land, and assigning socially created value as against value of improvements added by the owner.

${ }^{33}$ Belshaw, op. cit. stepra note 34 , at 219 . In valuation, three values were assessed for each property: (1) unimproved value of land, (2) value of improvements, (3) capital value. An interesting provision of the law was that upon taxpayer's appeal from assessment and failure to reduce by the Valuer-General:

(r) If the objector refused to accept the Valuer's assessment of fair selling value, the property could be acquired at that valuation by the Crown.

(2) The owner could require the Crown to take over his land at official valuation if the Valuer refused to reduce his valuation to the level considered by the owner as fair selling value. 
making of improvements as such. There is considerable doubt whether the fundamental problem attacked, large estates, aggregation, and absentee holding, is of the same character and degree in this country. Australian and New Zealand experience has shown that assessment and listing of strictly unimproved values can be done, but that it is a matter of great practical difficulty and arbitrary decision, bringing in their train a flood of appeals, litigation, and administrative tangle. It has already been pointed out in connection with homestead exemptions that in many states classification on the basis of ownership and valuation would run counter to constitutional uniformity provisions, requiring amendments for enactment. Since the issue of discrimination is more clearly apparent in the case of the graduated land tax than in homestead exemption, in all probability the former would encounter stiffer opposition, both in the constitutional fight for enactment, and in subsequent administration.

The graduated land tax would probably be suited to administration only by the states rather than by local units, not only because of the complex technical and administrative factors involved (which would in all likelihood bring administration to the states' doorsteps through the Boards of Equalization and Appeal even under local responsibility), but because the heavy dependence of local governments upon the property tax for strictly revenue purposes would inhibit their use or enforcement of a property tax for a regulatory purpose. In the graduated land tax, in the event of non-payment of the tax or failure to subdivide and sell, the property will be taken over by the governmental agency charged with enforcement of the tax. The penalty for non-payment is of course true of property taxes generally. The wide-spread break-down of the existing system of tax reversion would seem to be sufficient basis for presuming failure of enforcement by counties or other units primarily dependent for revenue on the property tax. It is not at all certain that such a measure could be enforced by the state, assuming it could be enacted.

It is doubtful that such fundamental changes in the entire system of property taxation as would be entailed would be warranted, considering what they might accomplish in promoting ownership on the part of tenants, ${ }^{37}$ since the dislocation of revenues and the readjustments in state and local finance made necessary in order to set in motion forces of any consequence might be out of all proportion to the benefits conferred.

\section{The Single $T_{A X}$}

The single tax approach to this problem, of which there are numerous modern variants, represents another version of the magnitude of change considered necessary, and indicates the degree to which basic institutional and administrative factors must be ignored and the theoretical vagaries which are involved. This analysis presumes that a tax equal to the "economic rent" of land reduces the salable value of land, offering all the opportunity of owning land and thus bringing about the diminution of tenancy. The concurrent elimination of taxes on incomes and capital saved

"The federal. government, of course, is effectively prevented from levying a tax upon real property according to value by the constitutional provision that direct taxes be apportioned according to population. 
would (according to this analysis) increase the net rate of interest on capital to those who save (unless and until increased saving again causes the rate to fall), further lessening the salable value of land by bringing about the capitalization of its reduced rent at a higher interest or discount rate. Thus, purchasing tenant farmers could pay taxes, or more than pay them, out of interest on their saving in purchase price. Elimination of taxes on commodities or consumption would assist the process of accumulation for land purchase.

This theoretical approach runs entirely counter to that embodied in special classification and exemption devices as applied to owner-operated family-size farms. In fact, it holds the relief of real estate in general, or agricultural property in particular, through increased state aid, tax limitation, classification or exemption measures, accompanied by substitution of other sources of tax revenue, to be detrimental to prospective landowners both through the increase of land values and the actual increase of their other tax burdens and the penalty on savings. This analysis presumes the tax factor to be much more significant as an influence upon land values than is likely to be the case in practice.

\section{Capital Gains Taxes}

A further tax measure advocated as a means of controlling land speculation is the imposition by the federal government of a specific tax on capital gains from the sale of land within a period of, say, three years from the time of purchase. Such a provision would be incorporated in the federal income tax law. This tax, made particularly heavy upon unearned net increment, is held to discourage absentee ownership, purchase for realization only, and keep land prices on a lower and more stable basis to assist prospective land owners. Here again, the device is a crude indirect method of control, probably cumbersome out of proportion to the benefits it might convey in mitigating the evils of farm tenure. The legal or constitutional questions involved in singling out one type of capital gain for particularly heavy taxation and the use of the income tax for an obviously regulatory purpose are not here discussed.

The cost of administration of such a tax would undoubtedly exceed any long-run revenues derived from it over both prosperous and depression periods, although social control rather than revenue is the primary consideration in its application. The most important objections lie in the difficulties of efficient and equitable administration. Information as to actual considerations paid would have to be required for all transactions as a matter of record, and allowances would have to be made for enhancement of value by the owner, including repairs, remodeling, new building, reforestation, drainage and other improvements. Special investigation would be required to prevent evasion through fictitious ownership and to avoid injury through unavoidable or forced sale. Almost insurmountable obsfacles in checking, obtaining authentic records of costs of acquisition, proof of period held, identification of properties (subdivision), and appraisal would be encountered. It should be realized that capital gains may arise from: (I) shifts in the general price level of commodities; (2) changes in the value of money; (3) accretions due to time alone; 
(4) changes in the relative value of property; (5) improvements. The realization of capital gains may come about through: (r) transfer of investments; (2) forced sale of property, as in the case of moving; (3) a large amount of improvement over a short period; (4) realization for its own sake, as in liquidation in order to retire; and (5) speculation to derive appreciation rather than annual yield. The realization may be ordinary income to the speculator or trader and extraordinary income to the occasional investor or purchaser. The law could probably make no real distinction between them except on the basis of holding period; hence no real distinction between voluntary and involuntary gains. Obviously, each case could not be examined as to the necessity for sale. There is no practicable method of separating gains from changes in the price level or in the monetary unit from real gains; thus fictitious gains may actually be taxed. Whether the tax would. induce retention of properties in prosperous periods in order to avoid heavy taxes and cause artificial scarcity and inflationary prices will depend upon the severity of the tax and the period of holding selected. A short period of holding would permit avoidance of the tax under most circumstances.

The problem of speculation may be intimately connected with the problem of controlling fluctuations in the general price level and be associated with short-run factors or long-run increases in the general price level. Proposals of this character should be made so definite and specific that the philosophy of taxation and equitableness upon which they are based can be thoroughly examined. Furthermore, there should be an indication of the exact nature and causes of the speculation which it is desired to curb.

\section{Concrusion}

There appears to be little merit in the several tax devices examined from the standpoint of measurably aiding in a program to promote farm security. Not only is there reasonable doubt as to their effectiveness in contributing to the accomplishment of the desired ends, but there is virtual certainty that they would set in motion a train of unfavorable consequences with reference to the general property tax system as a primary source of local governmental revenue. Certainly the general property tax system is in need of reform both as to equitableness and efficiency in administration. A readjustment in many state tax systems would be desirable with a view to establishing a better balance between revenue sources and relieving real estate. These problems should be attacked as such, however. Considering the present condition of its administration, the property tax would not conceivably be improved by encumbering it further with regulatory functions and ill-advised exemptions. It would seem that the promotion of farm ownership by operators and the diminution of tenancy could be more readily assisted by a direct attack on the problem through government purchase or financing of farm homes. Such supplementary aid as might be derived from the use of specially designed tax measures would probably not be sufficient to warrant the complications in tax laws and administration which would be set in motion. 